\title{
Site-Directed Mutagenesis to Assess the Binding Capacity of Class S Protein of Staphylococcus aureus Leucotoxins to the Surface of Polymorphonuclear Cells
}

\author{
L. Baba Moussa, ${ }^{1}$ S. Werner, ${ }^{2}$ M. Coraiola, ${ }^{3}$ D. A. Colin, ${ }^{2}$ D. Keller, ${ }^{2}$ \\ A. Sanni, ${ }^{1}$ M. Dalla Serra, ${ }^{3}$ H. Monteil, ${ }^{2}$ and G. Prévost ${ }^{2}$ \\ ${ }^{1}$ Département de Biochimie et de Biologie Moléculaire, Faculté des Sciences et Techniques, Université d'Abomey-Calavi, \\ BP 04-0320, Cotonou, Benin \\ ${ }^{2}$ Laboratoire de Physiopathologie et d'Antibiologie Bactériennes des Infections Emergentes et Nosocomiales, UPRES EA 3432, \\ Institut de Bactériologie de la Faculté de Médecine de Strasbourg, Hôpitaux Universitaires de Strasbourg, Université Louis Pasteur, \\ 3 rue Koeberlé, 67000 Strasbourg, France \\ ${ }^{3}$ CNR_ITC, Istituto di BioFisica, Università di Trento, Via Sommarive 1838050 Trento, Italy
}

Received 13 August 2005; Revised 30 November 2005; Accepted 4 December 2005

\begin{abstract}
Staphylococcal leucotoxins result from the association of class S components and class $\mathrm{F}$ component inducing the activation and the permeabilization of the target cells. Like $\alpha$-toxin, the leucotoxins are pore-forming toxins with more than $70 \% \beta$-sheet. This was confirmed by attenuated total reflectance Fourier transform infrared (ATR-FTIR) spectroscopy. In addition, threonine 28 of a predicted and conserved $\beta$-sheet at the $\mathrm{N}$-terminal extremity of class $\mathrm{S}$ proteins composing leucotoxins aligns with histidine 35 of $\alpha$-toxin, which has a key role in oligomerization of the final pore. Flow cytometry was used to study different aminoacid substitutions of the threonine 28 in order to evaluate its role in the biological activity of these class S proteins. Finally, results show that threonine 28 of the leucotoxin probably plays a role similar to that of histidine 35 of $\alpha$-toxin. Mutations on this threonin largely influenced the secondary interaction of the class $\mathrm{F}$ component and led to inactive toxin.
\end{abstract}

Copyright (C) 2006 L. Baba Moussa et al. This is an open access article distributed under the Creative Commons Attribution License, which permits unrestricted use, distribution, and reproduction in any medium, provided the original work is properly cited.

\section{INTRODUCTION}

Staphylococcus aureus (S aureus) is one of the most frequently isolated bacterium in hospital routine, fearing infections that may affect any organs and tissues. Having developed resistance to most of antimicrobials, it is now responsible for $5-15 \%$ of nosocomial infections, depending on hospital sites and services [1]. The pathogenicity of this bacterium is caused by a series of adhesion factors [2] and toxins. Among these toxins, staphylococcal leucotoxins are a family of bicomponents toxins [3] that result from the association of class $\mathrm{S}$ and class $\mathrm{F}$ components that interact sequentially and synergistically [4], inducing the activation and the permeabilization of the target cells. The class $S$ protein first binds to the membrane of target cells and then allows the secondary binding of class $\mathrm{F}$ component. These toxins target polymorphonuclear cells (PMNs), monocytes, macrophages, and erythrocytes [5, 6]. Among this family of toxins, Panton-Valentine leucocidin (LukS-PV + LukF-PV) and gamma-hemolysin, which generates two toxins ( $\mathrm{HlgA}+$ $\mathrm{HlgB}$ and $\mathrm{HlgC}+\mathrm{HlgB}$ ), activate response of specific cells via a $\mathrm{Ca}^{2+}$ influx and form lethal transmembrane pores. LukS$\mathrm{PV}, \mathrm{HlgA}$, and $\mathrm{HlgC}$ are class $\mathrm{S}$ components, while LukF$\mathrm{PV}$ and $\mathrm{HlgB}$ are class $\mathrm{F}$ components (Figure 1). The genes encoding these toxins have been cloned and sequenced [710]. Sequence homologies are very important inside the two classes of proteins. Identities are up to $55-70 \%$ for class $S$ and $70-80 \%$ for class $\mathrm{F}$ proteins, but only $18-25 \%$ between the two classes $[11,12]$. Additional homologies exist between the two classes of proteins and other pore-forming toxins such as with staphylococcal $\alpha$-toxin [13]. Like $\alpha$-toxin of $S$ aureus, leucotoxins are pore-forming toxins with predominant $\beta$-sheet [13]. By aligning leucotoxins and $\alpha$-toxin (Figure 2), Thr28 appears preserved into a predicted $\beta$-sheet at the $\mathrm{N}$-terminal extremity of the leucotoxins and corresponds to His35 of $\alpha$-toxin [14]. His 35 has a role in the protein oligomerization and plays a critical role in its function [15]. The aim of this work was to study the functional tolerance 


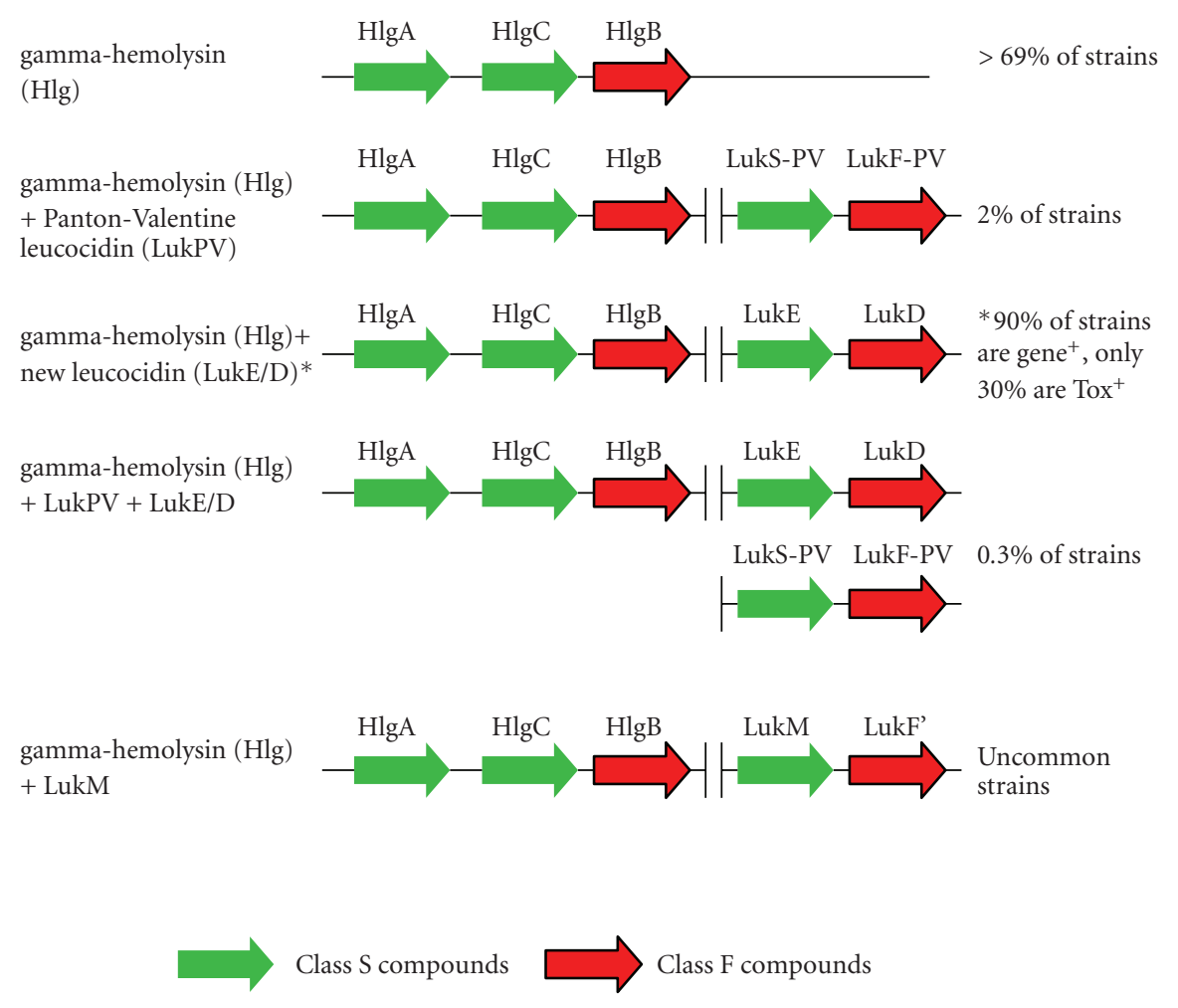

FIGURE 1: Distribution of the genes expressing leucotoxins of $S$ aureus.

\begin{tabular}{|c|c|c|}
\hline$\alpha$-toxin & 31 & E NGMHKK V F Y S F I DDK \\
\hline LukE & 25 & W - GV T QNVQ F D F V K D K \\
\hline LukS-PV & 25 & W- GV T QN I Q F D F V KD K \\
\hline $\mathrm{HlgA}$ & 25 & $\mathrm{~L}-\mathrm{A}$ I T QN I QFDF VKDI \\
\hline $\mathrm{H} \lg \mathrm{C}$ & 27 & W- GV T QN I Q F D F V KD \\
\hline LukM & 25 & W- GVT QNVQF D F V KD \\
\hline
\end{tabular}

FIgURE 2: Partial alignment $\alpha$-toxin sequence and class S component sequence of the leucotoxins.

by leucotoxins of different substitutions of threonine 28 of a class $S$ protein. Some of the mutations were predicted to disrupt the second $\beta$-sheet at the $\mathrm{N}$-terminal extremity. The secondary structure alteration of the purified mutated proteins was confirmed by Fourier transform infrared spectroscopy, and their biologicals activities were evaluated by flow cytometry onto human circulating PMNs and rabbit erythrocytes.

\section{MATERIALS AND METHODS}

\section{Cloning and sequencing of the mutated proteins}

DNA fragments corresponding to secreted proteins and containing the putative $3^{\prime}$ inverted repeats were amplified via dedicated oligonucleotides containing EcoR 1 restriction sequences at their $5^{\prime}$-end. After a further EcoR 1 restriction, the amplified DNA fragments were cloned in the EcoR1dephosphorylated pGEX-6P-1 (Amersham Biosciences, Orsay, France) expression vector. The correctly oriented recombinant plasmids were used as templates for any of the mutations discussed in this work. Site-directed mutagenesis was achieved by using the Quick Change Mutagenesis kit (Stratagene, Amsterdam, The Netherlands). Briefly, reactions were performed in the presence of $5 \mathrm{ng}$ of template $(5.8 \mathrm{~kb})$, $0.25 \mathrm{mM}$ dNTP, $0.4 \mathrm{nM}$ of each dedicated oligonucleotide, and $5 \mathrm{U}$ of Pfu Turbo DNA polymerase in $50 \mu \mathrm{L}$. Temperatures of hybridization, elongation, and denaturation were $50^{\circ} \mathrm{C}, 68^{\circ} \mathrm{C}$, and $95^{\circ} \mathrm{C}$ during 30 seconds, 3 minutes, $30 \mathrm{sec}-$ onds, and 1 minute, respectively. Initial templates were eliminated with an 80 minutes $D p n \mathrm{I}$ restriction, and $2.5 \mu \mathrm{L}$ of the resulting mixture was used for transformation of $80 \mu \mathrm{L}$ of XL1 Blue E coli XL1 Supercompetent Blue cells [recA1 endA1 gyrA96 thil hsdR17 supE44 relA1 lac ( $\mathrm{F}^{\prime}$ pro $\mathrm{AB}$ lac ${ }^{\mathrm{9}}$ $Z \Delta \mathrm{M} 15 \operatorname{Tn} 10\left(\right.$ tet $\left.\left.\left.^{\mathrm{r}}\right)\right)\right]$. Mutated genes were sequenced from Plasmid Midi kit preparations Qiagen (Paris, France), and plasmids only containing the mutation were electroporated at $1.8 \mathrm{kV}, 200 \mathrm{Ohms}, 25 \mu \mathrm{Fd}$ in $80 \mu \mathrm{l}$ of $E$ coli BL21 [F-, ompT, hsdS $\left(r B^{-}, m B^{-}\right)$, gal $\left.(52,53)\right]$ (Amersham Biosciences, Orsay, France) previously stored at $-80^{\circ} \mathrm{C}$ at $2.0 \mathrm{~A}_{600} \mathrm{~nm}$ units in $0.1 \mathrm{mM}$ Hepes, $\mathrm{pH}$ 7.0. Electroporated cells were regenerated in SOC medium $(1 \%(\mathrm{w} / \mathrm{v})$ tryptone, $0.5 \%(\mathrm{w} / \mathrm{v})$ yeast extract, $10 \mathrm{mM} \mathrm{NaCl}, 10 \mathrm{mM} \mathrm{MgCl}, 10 \mathrm{mM} \mathrm{MgSO}_{4}$, 
$20 \mathrm{mM}$ glucose, $\mathrm{pH} 7.0$ ) for 1 hour at $37^{\circ} \mathrm{C}$. Transformed bacteria were finally treated and plated as recommended (GST Gene Fusion System (Amersham Biosciences, Orsay, France)).

\section{PURIFICATION OF E COLI RECOMBINANT LEUCOTOXIN COMPONENTS}

The mutated proteins were purified as glutathione-Stransferase-(GST) fusioned leucotoxins. Recombinant $E$ coli BL 21 mutated clones were inoculated from a starter culture into $2 \times 400 \mathrm{~mL}$ of TY medium filled in two-liter Erlenmeyer flasks, and cultivated for 6 hours before overnight induction of the GST-fusioned protein with $0.2 \mathrm{mM}$ IPTG. Bacteria were harvested by centrifugation and concentrated to $30 \%(\mathrm{w} / \mathrm{v})$ into $30 \mathrm{mM} \mathrm{NaH}_{2} \mathrm{PO}_{4}, 150 \mathrm{mM} \mathrm{NaCl}$, and $1 \mathrm{mM}$ EDTA, pH 7.0. Then, bacteria were disrupted at 9000 psi with a French pressure press (SLM Instruments, Ill, USA; Bioritech, Joinville, Juine, France). Cell debris were discarded by a 30 -minute centrifugation at $30000 \times g$ at $6^{\circ} \mathrm{C}$, and GST activity was measured at $340 \mathrm{~nm}$ as recommended. A volume of lysate equivalent to $4 \mathrm{mg}$ of titrated GST was applied onto a Glutathione Sepharose 4B (Pharmacia) column equilibrated with $60 \mathrm{mM}$ Tris-HCl, pH 8.0. The fusion protein was eluted in the same buffer containing $30 \mathrm{mM}$ glutathion, and materials were further digested overnight by $5 \mathrm{U}$ of PreScission protease (Pharmacia) per mg of eluted proteins. The leucotoxin components were purified through a $1.35 \mathrm{M}$ to $0.45 \mathrm{M}\left(\mathrm{NH}_{4}\right)_{2} \mathrm{SO}_{4}$ gradient applied on an alkylsuperose fast performance liquid chromatography (Pharmacia). The proteins were eluted at $0.75 \mathrm{M}\left(\mathrm{NH}_{4}\right)_{2} \mathrm{SO}_{4}$. The pre-purified F components were dialyzed against $30 \mathrm{mM}$ MES, pH 6.3, and purified to homogeneity by a MonoS FPLC through a 0 to $150 \mathrm{mM} \mathrm{NaCl}$ gradient, with elution around $90 \mathrm{mM}$ $\mathrm{NaCl}$. Purified proteins were controlled by SDS-PAGE and radial gel immunoprecipitation and stored at $\mathrm{A}_{280 \mathrm{~nm}}=1.0$ at $-80^{\circ} \mathrm{C}$.

\section{Preparation of human polymorphonuclear cells}

Twelve milliliters of J-Prep solution (TechGen, Les Ulis, France) were added to $30 \mathrm{~mL}$ of buffy coats from healthy donors diluted with $10 \mathrm{~mL}$ of $0.9 \%(\mathrm{w} / \mathrm{v}) \mathrm{NaCl}$, and centrifuged for 20 minutes at $800 \times g$ at room temperature. The cell pellet was suspended in $40 \mathrm{~mL}$ of $0.9 \%(\mathrm{w} / \mathrm{v}) \mathrm{NaCl}$, $1.5 \%(\mathrm{w} / \mathrm{v})$ dextran and left to sedimentation for $30 \mathrm{~min}$ utes. The supernatant was carefully removed and then centrifuged at room temperature at $800 \times g$ for 10 minutes. The new supernatant was discarded and the erythrocytes pellet containing PMNs was resuspended and lysed into $18 \mathrm{~mL}$ of apyrogenic water for 45 seconds, before complementing the suspension with $2 \mathrm{~mL}$ of $9 \%(\mathrm{w} / \mathrm{v}) \mathrm{NaCl}$. After two washing steps in $50 \mathrm{~mL}$ of $140 \mathrm{mM} \mathrm{NaCl}, 5 \mathrm{mM} \mathrm{KCl}, 10 \mathrm{mM}$ glucose, $0.1 \mathrm{mM}$ ethylene glycol-bis (beta-aminoethyl ether) $\mathrm{N}, \mathrm{N}, \mathrm{N}^{\prime}$, $\mathrm{N}^{\prime}$-tetraacetic acid, $10 \mathrm{mM}$ Hepes, and $3 \mathrm{mM}$ Tris Base $(\mathrm{pH}$ 7.3 ), the cells were suspended and adjusted to $2 \times 10^{6}$ cells $/ \mathrm{mL}$ in the same buffer. The latter buffer was used to wash the cells treated with the $\mathrm{Ca}^{2+}$-specific fluorescent probe Fluo-4 (Molecular Probes, Eugene, Oregon, USA).

\section{Labelled proteins}

LukS-PV G10C, a functional cystein mutated protein [16], was labelled with fluorescein 5-maleimide (Molecular Probes, Lerden, The Netherlands) at a 5-fold excess for a $10 \mu \mathrm{M}$ protein solution for 30 minutes at room temperature in $50 \mathrm{mM} \mathrm{Na}_{2} \mathrm{HPO}_{4}, 0.15 \mathrm{M} \mathrm{NaCl}, 1 \mathrm{mM}$ EDTA, and $\mathrm{Na}_{2}, \mathrm{pH}$ 7.0. The coupling reaction was stopped by the addition of $10 \mathrm{mM} \beta$-mercaptoethanol. The mixture was then desalted, and the coupling yield was determined by the ratio of the determined concentration of fluorescein $\left(\varepsilon_{490 \mathrm{~nm}}=\right.$ $\left.81,900 \mathrm{~cm}^{-1} \cdot \mathrm{mol}^{-1}\right)$ and that of the protein determined by the Bradford's titration (Biorad, Ivry, Seine, France).

\section{Flow cytometry measurements}

Experiments were made with $5 \times 10^{5}$ cells $/ \mathrm{mL}$ loaded in $5 \mu \mathrm{M}$ Fluo-4 solutions during 1 hour at $37^{\circ} \mathrm{C}$, then washed and resuspended in the presence of $1.1 \mathrm{mM} \mathrm{Ca}^{2+}$ for the evaluation of the $\mathrm{Ca}^{2+}$ entry. Each component constituting the leucotoxins was generally added at $1 \mathrm{nM}$. Flow cytometry measurements were performed by using a FacSort cytometer (Becton Dickinson, Le Pont de Claix, France) equipped with a $15 \mathrm{~mW}$ argon laser tuned at $488 \mathrm{~nm}$. Forward (FSC) and side (SSC) light scatter dot plots acquired from 3000 purified leucocytes were classically gated $[14,17]$. Fluo-4 fluorescence due to the calcium penetration was recorded from the fluorescence light 1 (FL1: $\left.\lambda_{\mathrm{Em}}=530 \mathrm{~nm}\right)$ every 30 seconds during 45 minutes. After basic fluorescence subtraction, results were compared to the maximum fluorescence obtained with controls which indicated the potentiality of the different pairs of leucotoxins for the opening of $\mathrm{Ca}^{2+}$ channels. The fluorescence light 3 (FL3: $\lambda_{\mathrm{Em}}=650 \mathrm{~nm}$ ) was used to record the fluorescence of ethidium applied at $25 \mathrm{nM}$ together with the leucotoxins. This fluorescence increased when the molecule entered the cells by the pores formed through the plasma membrane and combined with nucleic acids. Means from four series of significant data, at least, obtained from PMNs of four or more different donors were calculated by Lysis 2TM software (Becton Dickinson), and the results were expressed as regression curves by using SigmaPlot facilities as mean percentages of maximum fluorescence detected from controls. Standard deviations were not shown for clarity of the figures, but did not vary more than $\pm 6 \%$ as determined by SigmaPlot 8.0 resource.

By using a full functional fluorescein-labelled LukS-PV G10C, the binding abilities of LukS-PV and inactive mutants combined with $3 \mathrm{nM}$ LukF-PV were determined by competition experiments in the absence of extracellular calcium, using a fixed concentration of $20 \mathrm{nM}$ of the labelled LukS-PV G10C and variable concentrations of $1,5,10,20,50,100$, and $200 \mathrm{nM}$ of the mutated proteins. The residual fluorescence at the cell surface was gated during 50 minutes after the application of the protein couples $\mathrm{X}+\mathrm{LukF}-\mathrm{PV}$, in order 


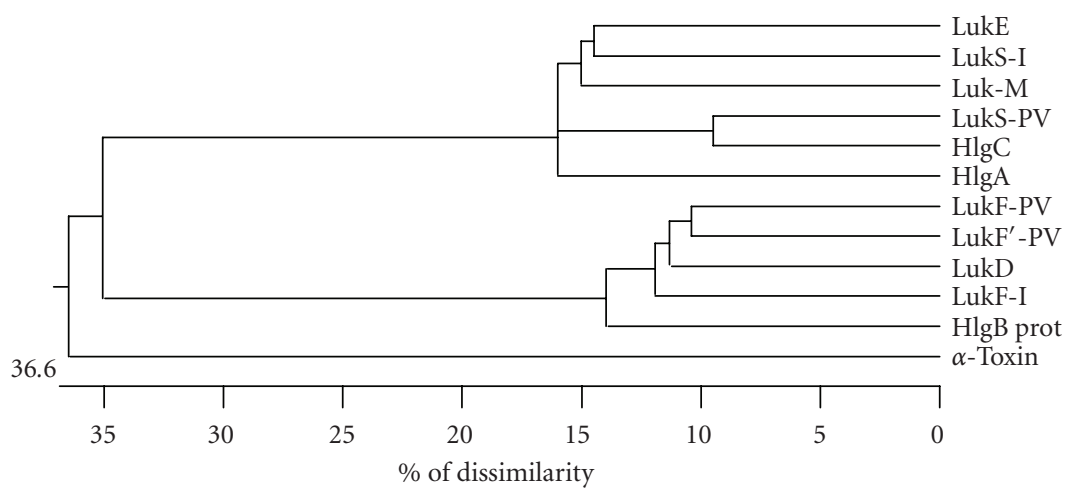

FIGURE 3: Philogenetic tree of peptidic homologies between the leucotoxins and $\alpha$-toxin of $S$ aureus. Unit $=$ Euclidian distance (DNA Star, Ltd, London).

to minimize the influence of lysed cells in the data. Apparent inhibition constants $\left(k_{\text {iapp }}\right)$ were deduced from projection to abscise the 50\% means fluorescence values (IC50), with the following equation:

$$
k_{\text {iapp }}=I C 50 / 1+[F] / K d_{F},
$$

where $[\mathrm{F}]$ is the concentration of the fluorescent LukF-PV LukS-PV Gly10Cys and $K_{d F}=3 \mathrm{nM}$ [18].

\section{Secondary structure determination by ATR-FTIR}

ATR-FTIR spectra were recorded on Biorad FTS 185 FTIR spectrometer equipped with DTGS detector with CSL window, a KBr beamspliter, and an ATR attachment by Specac. Typically 32 interferograms were collected, Fourier transformed to a nominal resolution of $0.5 \mathrm{~cm}^{-1}$, and averaged. The instrument was constantly purged with dry air. Spectra were corrected by a subtracted background obtained with an ATR crystal and no sample. The residual absorbance of $\mathrm{H}_{2} \mathrm{O}$ was subtracted to give an almost flat baseline between 1880 and $1720 \mathrm{~cm}^{-1}$. Before analysis, the leukotoxins were extensively dialyzed against $10 \mathrm{mM}$ Hepes ( $\mathrm{pH}$ 7.0). For the experiments, 28 to $40 \mu \mathrm{g}$ of each protein contained in $40 \mu \mathrm{L}$ of the given leukotoxin solution were deposited and dried in thin layer on one side of a 10 reflections $\mathrm{Ge}$ crystal $\left(45^{\circ} \mathrm{C}\right.$ cut): the crystal was housed in liquid cell and flushed with $\mathrm{D}_{2} \mathrm{O}$ saturated nitrogen for 45 minutes before collecting the reported spectra.

The ATR-FTIR spectra were processed using the Biorad Win-IR software. Spectra were dissolved to $2 \mathrm{~cm}^{-1}$, and the amide $\mathrm{I}^{\prime}$ band, between 1600 and $1700 \mathrm{~cm}^{-1}$, was curve-fitted with a sum of Lorentzians, using nonlinear least squares fitting of Levenberg-Marquadt method. No parameter was constrained. The relative contents of secondary structure elements were estimated by dividing the area of individual peak, assigned to particular secondary structures, according to Byler and Susi [19], by the area of the whole amide $\mathrm{I}^{\prime}$ band; the components around $1600 \mathrm{~cm}^{-1}$, resulting from the side chains, were excluded.

\section{RESULTS}

\section{Secondary structure prediction}

The secondary structure prediction for class $\mathrm{S}$ and class $\mathrm{F}$ proteins reveals significant homologies, as expected for proteins harbouring from 60 to $98 \%$ of sequence identity [20]. The sequence alignment by the software DNAStar of $\alpha$-toxins and two component leucotoxins of class $\mathrm{S}$ shows that their sequence identity is less than 26\% (Figure 2), but remained compatible with a common ancestor as shown on the philogenetic tree (Figure 3). These structural homologies have been unambiguously confirmed by the determination of three-dimensional structures of LukF-PV [21], and LukSPV [22]. Thr28 in the class $S$ of two component leucotoxins aligns with His35 of $\alpha$-toxin (Figure 2). As an attempt to verify whether threonine residue of these class $S$ leucotoxins has the same role as this His 35 , amino acid substitutions were introduced that would predictably disrupt the $\beta$-sheet of these class S proteins, which is highly conserved in the Nterminus region (Chou and Fassman, and Kite and Doolittle programs). Ten mutations were performed, eight on LukSPV (LukS-PV T28D, LukS-PV T28N, LukS-PV T28N+AK43, LukS-PV T28F, LukS-PV T28L, LukS-PV N30T, LukS-PV D34C, LukS-PV D34S), one on HlgA (HlgA T28D), and one on HlgC (HlgC T30D). The purified proteins showed apparent molecular masses comparable with the staphylococcal native proteins (data not shown). Substitutions of Thr28 by Asp in HlgA and HlgC induced a strong decrease in $\beta$ structure (Table 1) up to $12.5 \%$. In the case of HlgA T28D, such decrease is compensated by an increase in $\beta$-turn structure, whereas in the case of HlgC T30D, there is an increase in the unordered structure. For LukS-PV, there is a decrease in $\beta$-structure for all mutations (less than 3\%) except for LukSPV T28L (6.5\%), but these decreases remain low compared to $\mathrm{HlgA}$ and $\mathrm{HlgC}$ mutants (Table 1 ).

\section{Binding capabilities of the mutated proteins}

The binding capability of the mutated protein LukS-PV G10C was first tested on polymorphonuclear, monocytes, 
TABLE 1: Determination of the secondary structure of the leucotoxins by ATR-FTIR. The Lorentzian average corresponds to particular secondary structure (Byler and Susi). $\beta_{1}=$ antiparallel $\beta$-sheet, $\beta_{2}=$ parallel and antiparallel $\beta$-sheet, $\alpha=\alpha$-helice, t $=\beta$-turn and $r=$ unorganized structure. $\beta_{\text {total }}=\beta_{1}+\beta_{2}$. The errors following the independent testing are $\pm 5 \%$.

\begin{tabular}{l|cccccc}
\hline Proteins & $\beta \mathrm{t}$ & $\mathrm{t}$ & $\alpha$ & $\mathrm{r}$ & $\beta$ & $\beta$ total \\
\hline HlgA & 6.7 & 14 & 15 & 15 & 57 & 63 \\
HlgA T28D & 9.6 & 25 & 4 & 17 & 43 & 53 \\
HlgC & 4.3 & 21 & 11 & 5 & 58 & 62 \\
HlgC T30D & 4.7 & 24 & 11 & 14 & 45 & 49 \\
LukS-PV & 10 & 49 & 10 & 8 & 20 & 60 \\
LukS-PV T28D & 9 & 46 & 12 & 10 & 20 & 56 \\
LukS-PV T28N & 8 & 48 & 12 & 10 & 20 & 56 \\
LukS-PV T28N + & 9 & 48 & 14 & 11 & 17 & 57 \\
LuksPV T28F & 10 & 45 & 12 & 9 & 21 & 56 \\
LuksPV T28L & 7 & 46 & 11 & 12 & 22 & 53 \\
LukS-PV N30T & 9 & 50 & 12 & 11 & 17 & 59 \\
LukS-PV D34C & 6 & 53 & 13 & 13 & 13 & 56 \\
LukS-PV D34S & 9 & 47 & 13 & 11 & 18 & 57 \\
\hline
\end{tabular}

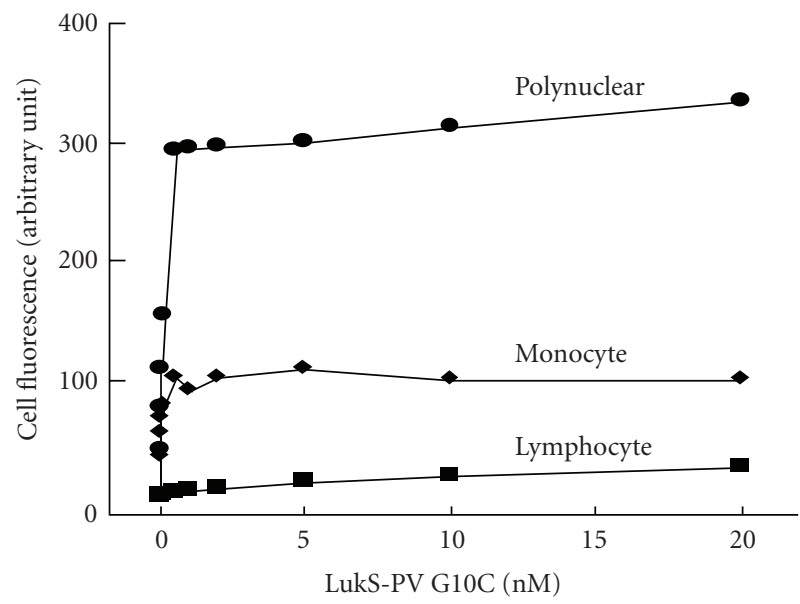

Figure 4: Determination by flow cytometry of LukS-PV G10C fluorescein-labelled association constant $(\lambda \mathrm{ex}=488 \mathrm{~nm}, \lambda \mathrm{em}=$ $5 \mathrm{~nm}$ ) with the human monocytes, polynuclears, and lymphocytes $\left(2 \times 10^{5}\right.$ cell $\left./ \mathrm{mL}\right)$. Polynuclear: $K_{D}=0.13 \mathrm{nM}$; monocyte: $K_{D}=$ 0.04. The LukS-PV Concentration is in $\mathrm{nM}$.

and lymphocytes. Figure 4 shows that the fluoresceinlabelled LukS-PV G10C is able to bind correctly to the target cells $\left(k_{\text {iapp }}=0.07 \mathrm{nM}\right)$. The binding on lymphocytes was not detectable. The fluorescent mutated LukS-PV G10C is functional (see below).

In order to determine whether the mutated LukS-PV proteins are able to bind to the polymorphonuclear, a binding competition was performed between these mutated proteins and the fluorescein-labelled LukS-PV G10C. Figure 5 shows a similar binding of all the mutated proteins in competition with the fluorescent LukS-PV G10C, except for LukSPV T28L for which a $k_{\text {iapp }}$ could not be determined. The apparent inhibition constants $\left(k_{\text {iapp }}\right)$ of these proteins are comparable to the estimated dissociation constant $\left(K_{D}\right)$ of the native protein (Figure 5). Another kind of binding competition was performed between each LukS-PV mutated protein and the class $\mathrm{F}$ component $\mathrm{HlgB}$ labelled with 5-[4, 6-dichlorotriazin-2-YL] amino-fluorescein (DTAF). Figure 6 shows that only the native LukS-PV allowed the secondary binding of HlgB-DTAF. When combined with the mutated protein HlgB-DTAF, LukS-PV mutants are not able to bind to the cell membrane (Figure 6).

\section{Calcium and ethidium entries induced by LukS-PV mutated proteins}

Calcium and ethidium entries were measured by flow cytometry. The calcium entry was measured in the presence of $1 \mathrm{nM}$ extracellular calcium and the ethidium entry was measured in the absence of calcium. Figure 7(a) shows that the native LukS-PV protein allows a strong entry of $\mathrm{Ca}^{2+}$ and an entry of ethidium. The entry of calcium induced by the mutated proteins is low. Two mutants, LukSPV T28L and LukS-PV T28N, displayed an entry of calcium. For the entry of ethidium, five mutants: LuksPV T28L, LukS-PV T28N, LukS-PV T28N+ 4 K43, LukS-P T28D, and LukS-PV D34S, displayed an entry of ethidium (Figures $7(\mathrm{~b})$ and 7(c)), while three mutated proteins: LukS-PV D34T, LukSPV D34C, and LukS-PV N30T, were as active as the native protein. 


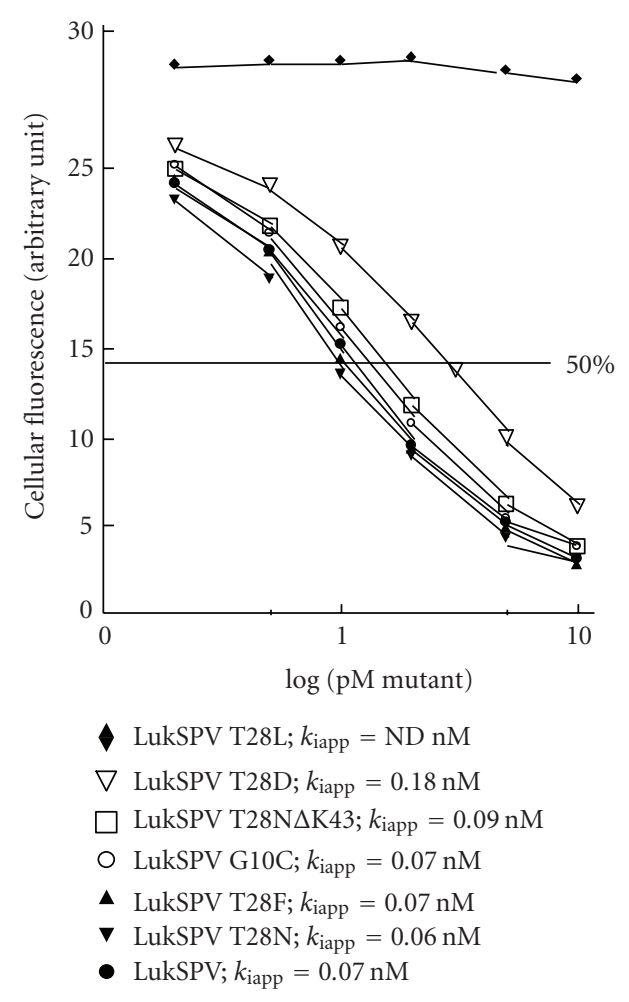

FIGURE 5: Competition between the fluorescent LukS-PV G10C and the mutated proteins and their binding to the cell, recorded by flow cytometry.

\section{DISCUSSION}

This work shows that the Thr28 of class S component of bicomponent leucotoxins may have a role in the whole structure because its substitution into a Leucine is responsible for a dramatic loss of the resulting LukS-PV. However, the Thr28 residue is a pore directly involved in the secondary binding and, may be, interaction with class $\mathrm{F}$ component. The decrease in the fluorescence of the native LukS-PV G10C (Figure 5) shows that there is a competition with the mutated protein. All the mutants have an affinity comparable to wild-type proteins $\left(k_{\text {iapp }} \sim 0.5 \mathrm{nM}\right)$ for LukS-PV receptor except T28L which seemed devoid of binding. The substitution of Thr28 by different amino acids (Asn(N), Asp(D), $\mathrm{Phe}(\mathrm{P}), \operatorname{Leu}(\mathrm{L}), \operatorname{Asn}(\mathrm{N}) \Delta \mathrm{Lys}(\mathrm{K}) 43)$ induced a decrease in $\beta$-structure up to $12.5 \%$ and had an influence on the secondary interaction of class $\mathrm{F}$ components, thus leading to inactive toxins. The mutations introduced in the class $\mathrm{S}$ proteins on Thr28 never prevent the binding of these proteins on their membrane ligand, that is, a receptor for LukS-PV [18], but hindered the secondary binding of class F component onto human PMNs. At this stage, $\mathrm{Ca}^{2+}$-activation and the pore-forming function of the bicomponent leucotoxins were both not possible despite their uncoupling remained possible $[16,23]$. The sequence identity between $\alpha$ toxin and the bipartite leucotoxins is less than $26 \%$, but remains compatible with the existence of a common ancestor

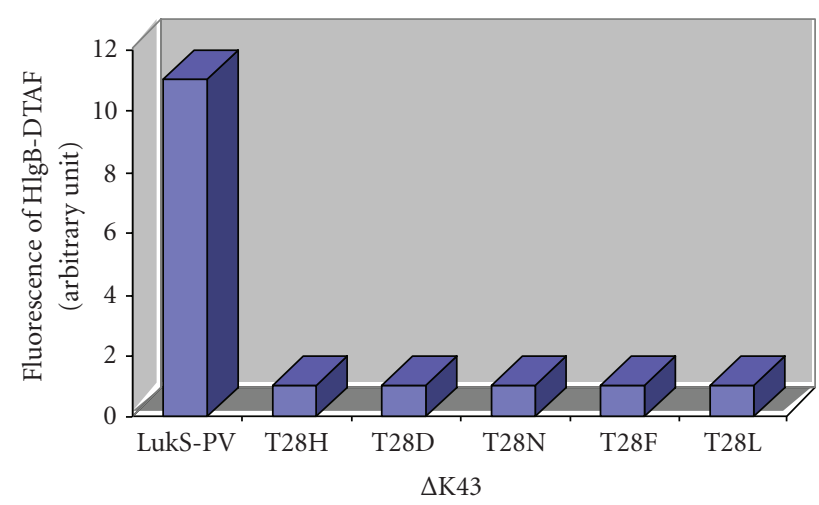

FIGURE 6: Determination of the secondary binding of a class F component mutated protein onto human PMNs. The determination of the binding is made by measuring the fluorescence of HlgBfluorescein $(0.75 \mathrm{nM})$ on bound mutated class $S$ proteins $(2 \mathrm{nM})$.

when amino acids, homologies, and structures are considered. Thr 28 of leucotoxins, as His 35 of $\alpha$-toxin, is probably an amino acid essential for oligomerization and for biological activity. Other substitutions, N30T and D34S, also affected the toxin activity suggesting that other residues than Thr28 may be involved in the interaction between the two subunits constituting leucotoxins. However, although the leucotoxins are members of the superfamily of $\beta$-barrel poreforming toxins, they differ from similar toxins like $\alpha$-toxin in some aspects. Their binding onto PMN membranes could be accompanied by the activation of a receptor, while these cells are not sensitive to $\alpha$-toxin [18]. On one hand, pores formed by bipartite leucotoxins are more selective to monovalent cations ( $\mathrm{Na}+, \mathrm{K}+$, ethidium) [24]. Oligomerization of bicomponent leucotoxins may involve residues at similar positions as for $\alpha$-toxin, but one amino acid Tyr101 of $\alpha$-toxin aligns with Tyr99 of $\mathrm{F}$ components of leucotoxin, and Tyr99 on HlgB or LukF-PV structures does not look accessible $[21,25]$. In conclusion, the substitutions made on Thr28 point out its key role in the oligomerization and the function of the staphylococcal leucotoxins. This observation confirmed a previous study which showed that when Thr28 of HlgA (or the corresponding Thr30 of HlgC) was substituted by Asp, the mutants were still able to bind target cells and compete with the wild type proteins, but the subsequent binding of $\mathrm{HlgB}$ was abolished, with a complete loss of biological activity [14]. This was observed with human PMNs, erythrocytes, and PC-Cho small unilamellar vesicles. Thr28 of HlgA aligns with His35 of $\alpha$-toxin, a crucial residue for monomer-monomer interactions $[15,26]$. As leucotoxins are naturally devoid of cysteines into their structure, mutagenesis approach might be interesting to stabilize heterodimers of leucotoxins in order to assess the amino acids involved in these interactions between $\mathrm{S}$ and $\mathrm{F}$ proteins of bipartite leucotoxins. The determination of the three-dimensional structures of LukF-PV [21] and recently for LukS-PV [22] now enables to challenge some residues in these interactions. 


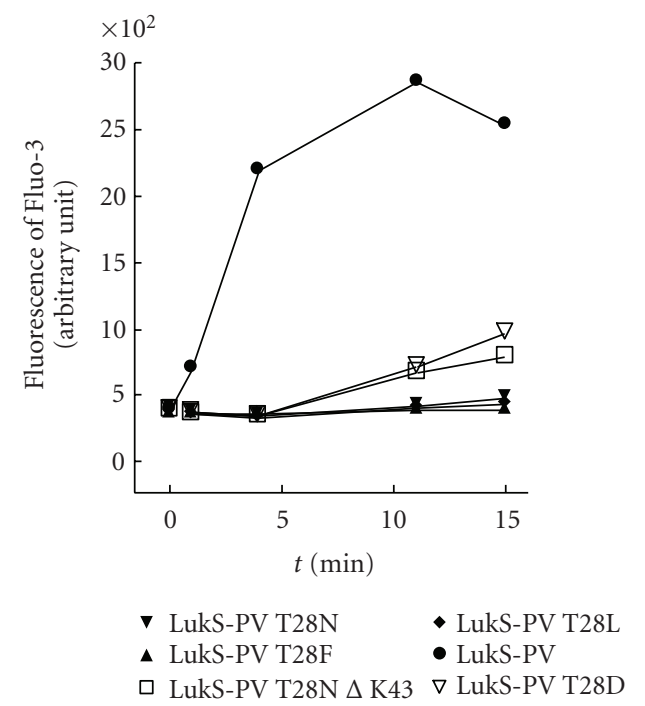

(a)

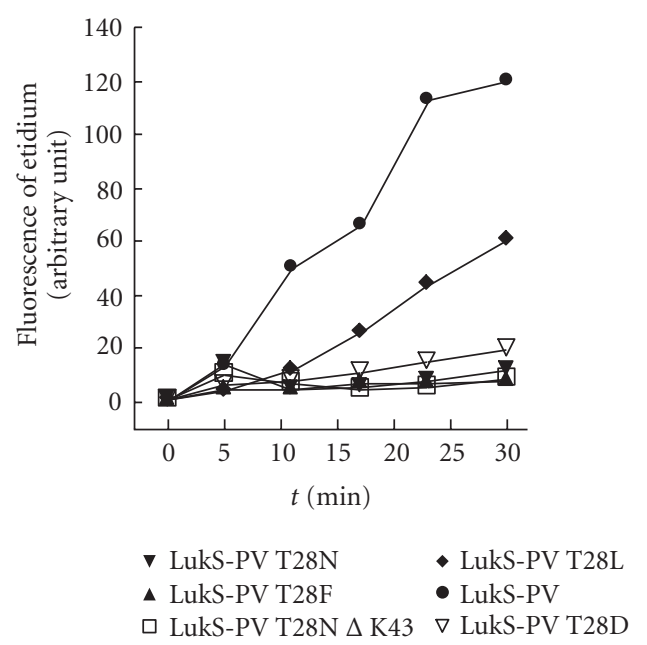

(b)
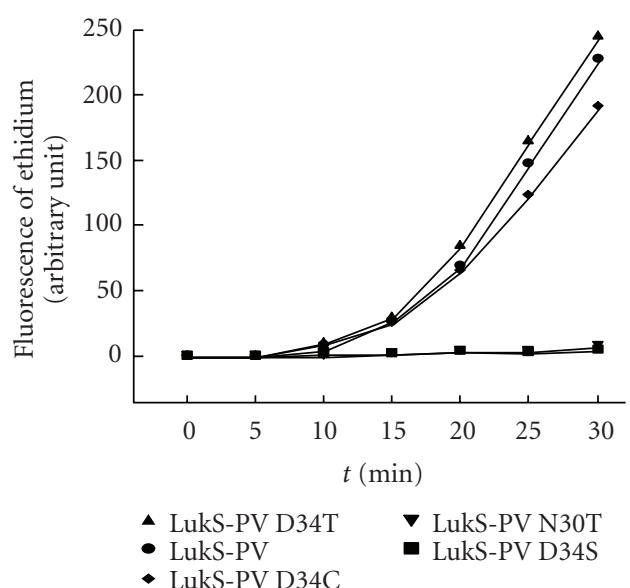

(c)

FIGURE 7: Determination by flow cytometry of (a) the opening of calcium channel in the presence of $1 \mathrm{mM}$ of calcium by the measurement of the fluorescence intensity of Fluo-3 $(\lambda \mathrm{ex}=488 \mathrm{~nm}, \lambda \mathrm{em}=530 \mathrm{~nm})$ and $(\mathrm{b})$, (c) the formation of the pores into membranes in absence of calcium by the measuring of the fluorescence intensity of ethidium $(\lambda \mathrm{ex}=488 \mathrm{~nm}, \lambda \mathrm{em}=650 \mathrm{~nm})$ for LukS-PV and the mutated proteins $(2 \mathrm{nM})$ associated to LukF-PV $(0.75 \mathrm{nM})$ on the membrane of human PMNs $(2 \times 105 \mathrm{cells} / \mathrm{mL})$.

\section{ACKNOWLEDGMENTS}

This paper is dedicated in memoriam to G. Menestrina who tragically disappeared in 2004 and initiated biophysical evaluations of leucotoxins (ATR-FTIR). The authors thank Drs Stephane Bronner and Eric Martinez for English improvement. This work was supported by Grant EA-3432 from the Direction de la Recherche et des Etudes Doctorales. L. Baba Moussa was granted by the Agence Universitaire pour la Francophonie-AUF and the International Union of Biochemical and Molecular Biology Societies, he was further an Invited Professor at Université Louis Pasteur.

\section{REFERENCES}

[1] Kloos WE, Bannerman TL. Staphylococcus and micrococcus. In: Murray PR, Baron EJ, Pfaller MA, Tenover FC, Yolken RH, eds. Manual of Clinical Microbiology. 7th ed. Washington, DC: American Society for Microbiology Press; 1999:264-282.

[2] Foster TJ, Höök M. Surface protein adhesins of Staphylococcus aureus. Trends in Microbiology. 1998;6(12):484-488.

[3] Prévost G. The bi-component staphylococcal leucotoxins and $\gamma$-haemolysins (toxins). In: Alouf JE, Freer JH, eds. The Comprehensive Sourcebook of Bacterial Protein Toxins. London, UK: Academic Press; 1999:402-418.

[4] Prévost G, Colin DA, Staali L, et al. Les leucotoxines formant des pores de Staphylococcus aureus: variabilité des cellulescibles et deux processus pharmacologiques [Pore-forming leukotoxins from Staphylococcus aureus: variability of the target cells and 2 pharmacological processes]. Pathologie Biologie. 1998;46(6):435-441.

[5] Prévost G, Bouakham T, Piémont Y, Monteil H. Characterisation of a synergohymenotropic toxin produced by Staphylococcus intermedius. FEBS Letters. 1995;376(3):135-140. 
[6] Tomita T, Kamio Y. Molecular biology of the pore-forming cytolysins from Staphylococcus aureus, $\alpha$ - and $\gamma$-hemolysins and leukocidin. Bioscience, Biotechnology, and Biochemistry. 1997;61(4):565-572.

[7] Cooney J, Kienle Z, Foster TJ, O'Toole PW. The gammahemolysin locus of Staphylococcus aureus comprises three linked genes, two of which are identical to the genes for the $\mathrm{F}$ and $\mathrm{S}$ components of leukocidin. Infection and Immunity. 1993;61(2):768-771.

[8] Kaneko J, Kimura T, Kawakami Y, Tomita T, Kamio Y. Panton-Valentine leukocidin genes in a phage-like particle isolated from mitomycin C-treated Staphylococcus aureus V8 (ATCC 49775). Bioscience, Biotechnology, and Biochemistry. 1997;61(11):1960-1962.

[9] Supersac G, Prévost G, Piémont Y. Sequencing of leucocidin $\mathrm{R}$ from Staphylococcus aureus P83 suggests that staphylococcal leucocidins and gamma-hemolysin are members of a single, two-component family of toxins. Infection and Immunity. 1993;61(2):580-587.

[10] Gravet A, Baba Moussa L, Werner S, et al. Characterization of a novel 30\%-distributed staphylococcal leucotoxin and structure comparison with the other members of the toxin family. In: Hacker J, Alouf JE, Brand BC, et al., eds. Bacterial Protein Toxins. Stuttgart, Germany: Gustav Fischer; 1998:401402. Zentralblatt für Bakteriologie, Suppl. 29.

[11] Gouaux E, Hobaugh M, Song L. $\alpha$-Hemolysin, $\gamma$-hemolysin, and leukocidin from Staphylococcus aureus: distant in sequence but similar in structure. Protein Science. 1997;6(12): 2631-2635.

[12] Prévost G, Mourey L, Colin DA, Menestrina G. Staphylococcal pore-forming toxins. In: van der Goot FG, Compans RW, Cooper M, et al., eds. Pore-Forming Toxins. Vol 257. 2001:5383. Current Topics in Microbiology and Immunology.

[13] Lesieur C, Vécsey-Semjén B, Abrami L, Fivaz M, van der Goot FG. Membrane insertion: the strategies of toxins. Molecular Membrane Biology. 1997;14(2):45-64.

[14] Meunier O, Ferreras M, Supersac G, et al. A predicted $\beta$ sheet from class $\mathrm{S}$ components of staphylococcal $\gamma$-hemolysin is essential for the secondary interaction of the class F component. Biochimica et Biophysica Acta (BBA)/Biomembranes. 1997;1326(2):275-286.

[15] Walker B, Bayley H. Key residues for membrane binding, oligomerization, and pore forming activity of staphylococcal alpha-hemolysin identified by cysteine scanning mutagenesis and targeted chemical modification. The Journal of Biological Chemistry. 1995;270(39):23065-23071.

[16] Baba Moussa L, Werner S, Colin DA, et al. Discoupling the $\mathrm{Ca}^{2+}$-activation from the pore-forming function of the bicomponent Panton-Valentine leucocidin in human PMNs. FEBS Letters. 1999;461(3):280-286.

[17] Meunier O, Falkenrodt A, Monteil H, Colin DA. Application of flow cytometry in toxinology: pathophysiology of human polymorphonuclear leukocytes damaged by a pore-forming toxin from Staphylococcus aureus. Cytometry. 1995;21(3):241247.

[18] Gauduchon V, Werner S, Prévost G, Monteil H, Colin DA. Flow cytometric determination of Panton-Valentine leucocidin S component binding. Infection and Immunity. 2001; 69(4):2390-2395.

[19] Byler DM, Susi H. Examination of the secondary structure of proteins by deconvolved FTIR spectra. Biopolymers. 1986; 25(3):469-487.
[20] Prévost G, Supersac G, Colin DA, et al. The new family of leucotoxins from Staphylococcus aureus: structural and biological properties. In: Alouf JE, Freer J, Aitken R, Boulnois G, eds. Bacterial Protein Toxins. Stuttgart, Germany: Gustav Fischer; 1994:284-293. Zentralblatt für Bakteriologie, Suppl. 24.

[21] Pédelacq J-D, Maveyraud L, Prévost G, et al. The structure of a Staphylococcus aureus leucocidin component (LukF-PV) reveals the fold of the water-soluble species of a family of transmembrane pore-forming toxins. Structure. 1999;7(3):277287.

[22] Guillet V, Roblin P, Werner S, et al. Crystal structure of leucotoxin S component: new insight into the Staphylococcal $\beta$ barrel pore-forming toxins. The Journal of Biological Chemistry. 2004;279(39):41028-41037.

[23] Staali L, Monteil H, Colin DA. The staphylococcal poreforming leukotoxins open $\mathrm{Ca}^{2+}$ channels in the membrane of human polymorphonuclear neutrophils. Journal of Membrane Biology. 1998;162(3):209-216.

[24] Colin DA, Mazurier I, Sire S, Finck-Barbançon V. Interaction of the two components of leukocidin from Staphylococcus aureus with human polymorphonuclear leukocyte membranes: sequential binding and subsequent activation. Infection and Immunity. 1994;62(8):3184-3188.

[25] Olson R, Nariya H, Yokota K, Kamio Y, Gouaux E. Crystal structure of staphylococcal LukF delineates conformational changes accompanying formation of a transmembrane channel. Nature Structural Biology. 1999;6(2):134-140.

[26] Menzies BE, Kernodle DS. Site-directed mutagenesis of the alpha-toxin gene of Staphylococcus aureus: role of histidines in toxin activity in vitro and in a murine model. Infection and Immunity. 1994;62(5):1843-1847. 

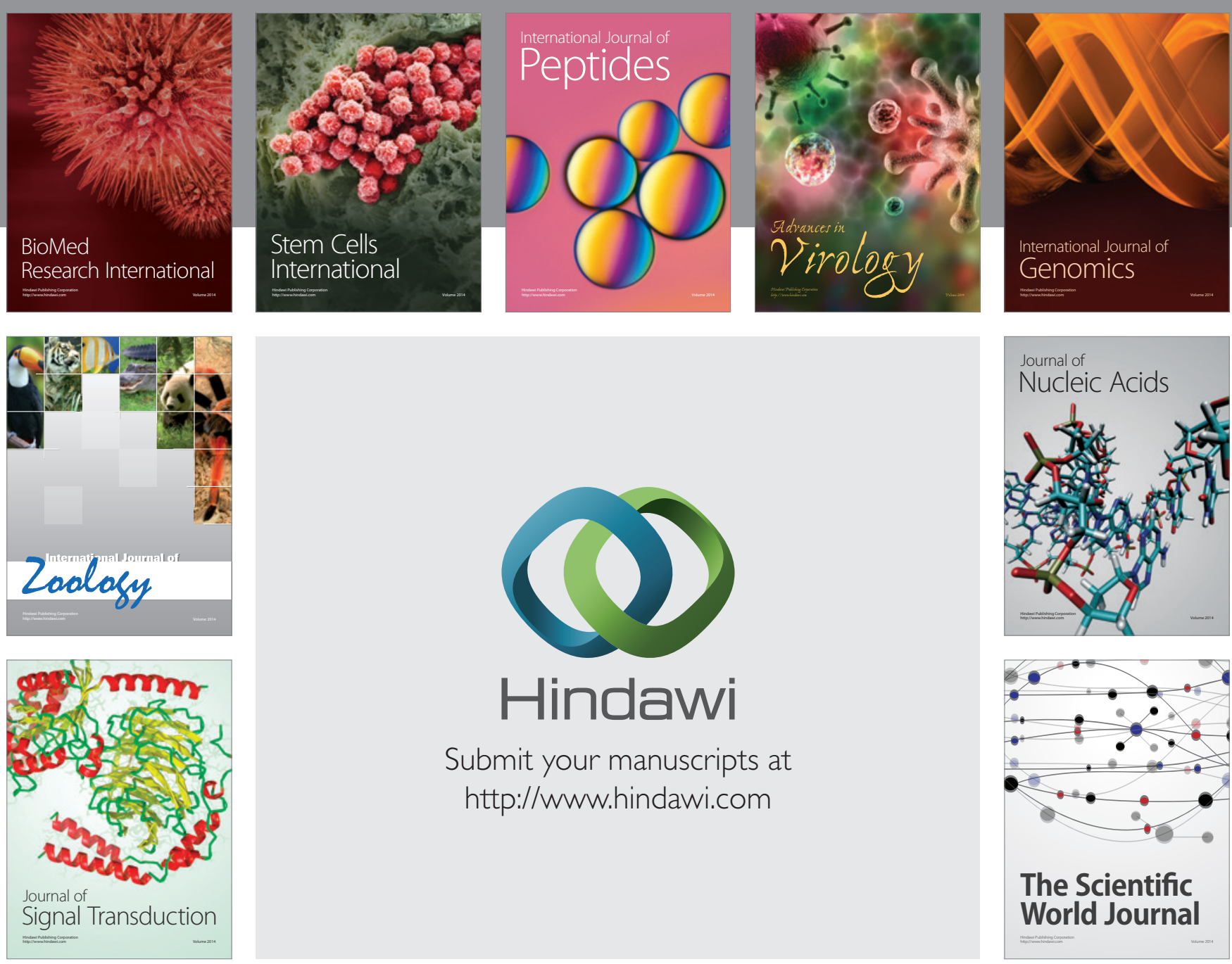

Submit your manuscripts at

http://www.hindawi.com
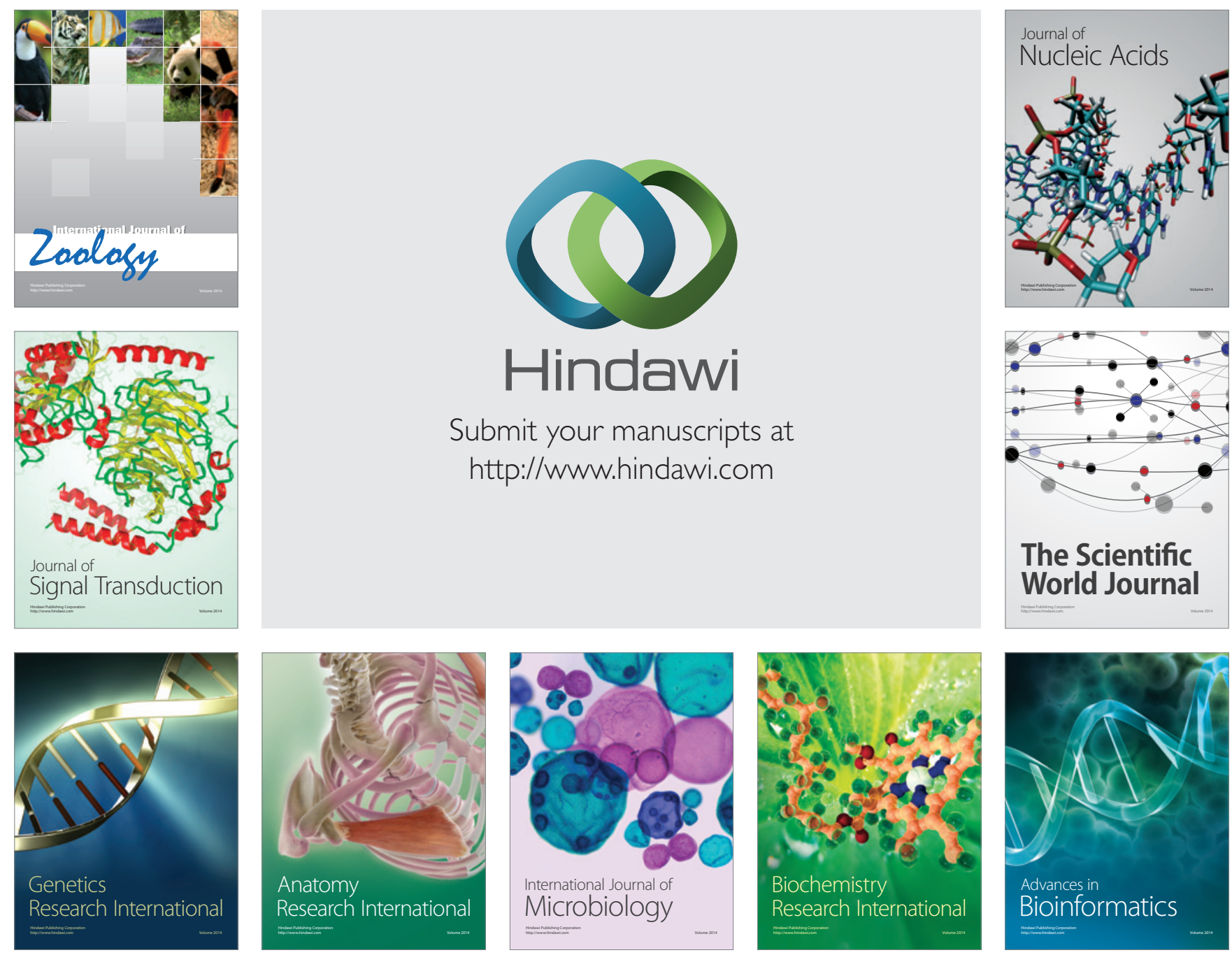

The Scientific World Journal
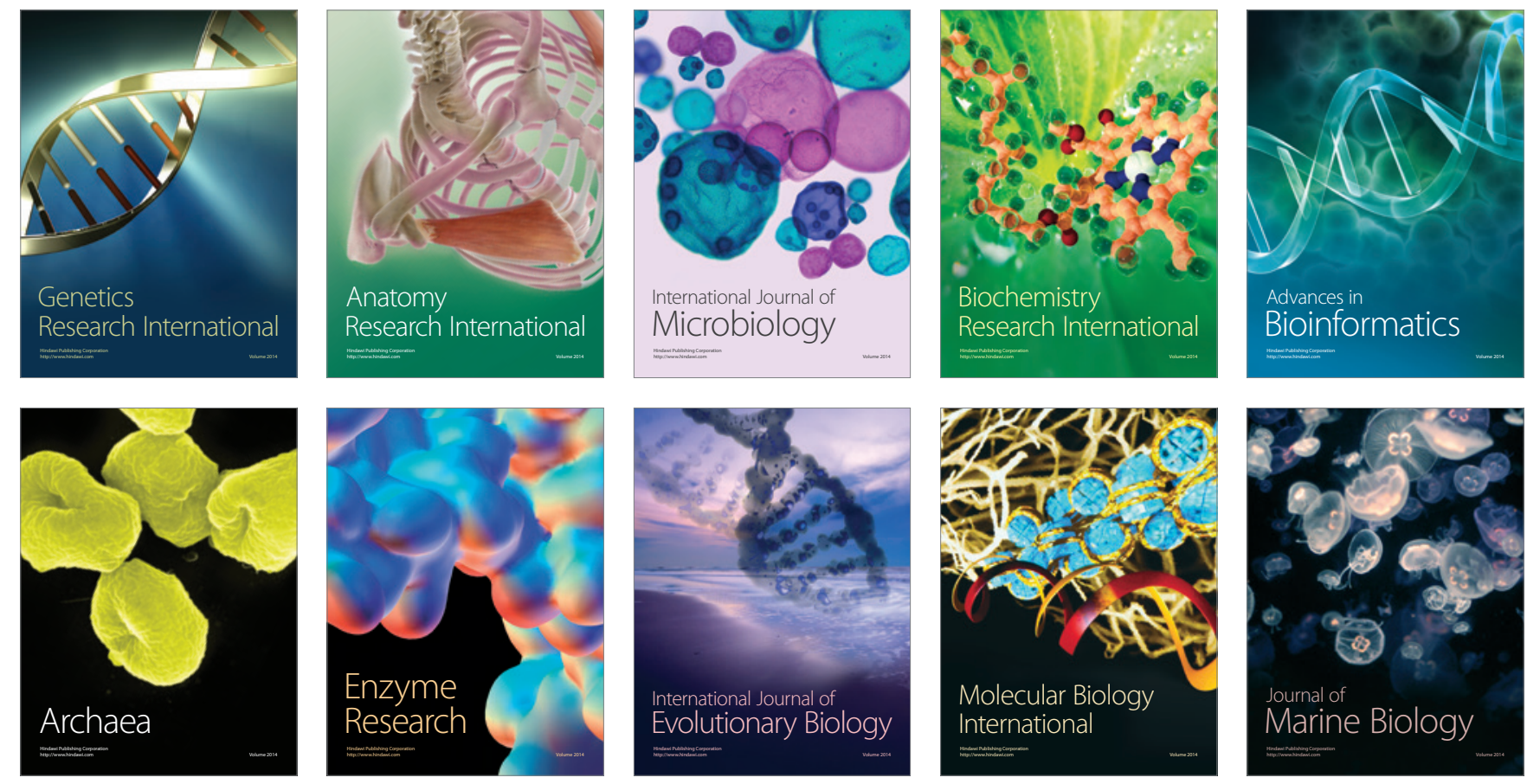